\title{
Optimasi Substitusi Saus Tomat dengan Ekstrak Buah Semu Jambu Monyet pada Formulasi Bumbu Marinasi Steak
}

\author{
Siti Susanti ${ }^{1)}$, Valentinus Priyo Bintoro ${ }^{1)}$, Antonius Hintono ${ }^{1)}$, Neti Zuniati ${ }^{1)}$, Fahmi Arifan ${ }^{2)}$ \\ ${ }^{1)}$ Program Studi Teknologi Pangan, Departemen Pertanian, Fakultas Peternakan dan Pertanian, \\ Universitas Diponegoro, Semarang, Indonesia \\ ${ }^{2}$ Program Studi Teknik Rekayasa Kimia Industri, Departemen Teknologi Industri, Sekolah Vokasi, \\ Universitas Diponegoro, Semarang, Indonesia \\ sitisusanti@live.undip.ac.id
}

(Article History: Received 13-09-2020; Accepted 28-10-2020; Published 29-10-2020)

\begin{abstract}
ABSTRAK
Ekstrak buah semu jambu monyet (EBSJM) sebagai bumbu marinasi menjadi salah satu aplikasi pemanfaatan jambu monyet di bidang pangan. Tujuan penelitian ini adalah menentukan level optimum EBSJM sebagai pensubstitusi saus tomat dalam formula bumbu marinasi ditinjau dari karakteristik fisikomikia dan hedoniknya. Empat level konsentrasi EBSJM dengan lima kali perulangan $(0,5,10$, dan $15 \%)$ dari proporsi saus tomat (v/v) ditetapkan dalam formula bumbu marinasi untuk menu steak. Produk bumbu steak untuk masing-masing formula selanjutnya dikarakterisasi fisikokimianya. Uji hedonik dilakukan dengan mengaplikasikan bumbu pada daging ayam yang diolah sebagai steak. Substitusi EBSJM pada saus tomat mempengaruhi karakteristik fisikokimia (viskositas, $\mathrm{pH}$, kadar air, dan total padatan) bumbu marinasi dan karakteristik hedonik (rasa dan tekstur) pada steak sebagai hasil aplikasi dari bumbu tersebut. Viskositas dan total padatan makin meningkat sedangkan kadar air makin menurun pada substitusi lebih dari 5\% ( $<<0,05)$. Penurunan $\mathrm{pH}$ bumbu makin bertambah seiring dengan penambahan substitusi hingga $10 \%$ $(\mathrm{p}<0,05)$. Uji hedonik menunjukkan substitusi $5 \%$ menghasilkan steak ayam yang paling disukai dari segi tekstur dan rasa $(\mathrm{p}<0,05)$. Substitusi saos tomat dengan EBSJM 5\% menghasilkan produk bumbu marinasi untuk steak yang kental, asam, pekat dan paling disukai.
\end{abstract}

Kata kunci : Ekstrak; bumbu; jambu monyet; marinasi

\section{Optimation on the Substitution of Tomato Sauce with Cashew Apple Extract in Formulation of Steak Marinade Seasoning}

\begin{abstract}
Extracts of cashew apple (EBSJM) as marinade seasoning is one of the applications of cashew apple utilization in the food sector. Study was aimed to determine the optimum level of EBSJM as a substitute for sauce in the marination seasoning formula reviewed from its physical and hedonic characteristics. Four levels of EBSJM concentration with five iterations $(0,5,10$, and $15 \%)$ of the sauce proportion $(\mathrm{v} / \mathrm{v})$ was defined in the marinade seasoning for steak. Steak seasoning products for each formula were further characterised by physicalochemistry. EBSJM substitution to tomato sauce affected the viscosity, $\mathrm{pH}$, moisture content, and total solids of marinade seasoning and hedonic characteristics (taste and texture) in the steak as a result of the application of the seasoning. Viscosity and total solids increased while water levels decreased at substitutions by more than $5 \%$ $(\mathrm{p}<0.05)$. The decrease in seasoning $\mathrm{pH}$ increased in line with the addition of substitutions up to $10 \%$ ( $\mathrm{p}<0.05)$. Hedonic tests showed a 5\% substitution resulting in the most preferred chicken steak in terms of texture and taste ( $\mathrm{p}<0.05)$. The substitution of tomato sauce with EBSJM 5\% obtained the marinade products for steaks that were dense, sour, concentrated, and most preferred.
\end{abstract}

Keywords: Cashew apple; extracts; margination; seasonings 


\section{PENDAHULUAN}

Steak merupakan sepotong daging yang biasanya dimasak dengan dipanggang. Saat ini steak adalah produk pangan yang sedang menjadi trend karena disukai semua kalangan, aromanya yang smokey, teksturnya yang lembut dan rasanya yang gurih sehingga merupakan hidangan special (Kerth, 2016). Sebelum proses pemanggangan umumnya daging akan dimarinasi terlebih dahulu dengan suatu bumbu dengan tujuan untuk meningkatkan citarasa (Ježek et al., 2020). Selain bumbu, marinasi juga dapat dilakukan dengan minyak makan, asam, rempah dan berbagai bahan lainnya misalnya jus atau ekstrak buah-buahan (Trabelsi et al., 2018).

Buah semu jambu monyet (BSJM) adalah salah satu buah yang sebelumnya pernah digunakan sebagai bahan marinasi daging dengan tujuan untuk menghambat pertumbuhan bakteri (Susanti et al., 2018). Aktivitas antibakterial dalam BSJM disebabkan karena buah tersebut kaya akan senyawa fenol dan fenolik (Kaprasob et al., 2017). BSJM juga mengandung beberapa senyawa fitokimia lain diantaranya flavonoid, steroid, triterpen, fenolik dan minyak atsiri, asam anakardat, steroid, triterpenoid dan glikosida (Das \& Arora, 2017). Selain itu ternyata BSJM kaya vitamin C, bahkan lebih tinggi daripada buah jeruk dan tomat (Oliveira et al., 2020). Selama ini tomat sebagai saus sangat lazim ditambahkan pada suatu resep bumbu untuk mengolah daging menjadi steak. Sayangnya hingga kini, pemanfaatan BSJM di bidang marinasi daging berikut terkait aplikasinya belum pernah dilakukan secara optimal.

Pada kajian ini, dicoba untuk mengaplikasikan BSJM yang telah diekstrak untuk menjadi salah satu komponen penyusun bumbu steak menggantikan sebagian proporsi tomat. Oleh karena itu, melalui tinjauan fisikokimia dan hedonik, penelitian ini dilakukan untuk mencari optimasi proporsi ekstrak BSJM yang dapat mensubstitusi saus tomat sebagai bumbu marinasi. Informasi yang dihasilkan dalam kajian ini diharapkan dapat meningkatkan ekstensifikasi pemanfaatan BSJM sebagai bahan tambahan alternatif dalam bidang pengolahan daging.

\section{METODE PENELITIAN}

Bahan yang dibutuhkan yaitu buah semu jambu monyet matang, etanol 70\%, minyak, bawang merah, bawang putih, paprika merah, saus tomat, gula palem, kecap inggris, merica hitam kasar, garam, aquades, dan buffer fosfat $\mathrm{pH} 4 \& 7$. Alat-alat yang digunakan yaitu pisau, saringan (diameter lubang $1 \mathrm{~mm}$ ), kertas saring, timbangan analitik, Viscometer Ostwald, $\mathrm{pH}$ meter, cawan petri, oven, desikator, labu takar, gelas ukur, Erlenmeyer, pipet, handheld refraktometer, dan gelas beker.

\section{Metode}

\section{Pembuatan Ekstrak Buah Semu Jambu Monyet (EBSJM)}

Pembuatan EBSJM mengacu pada (Susanti et al., 2018) yang telah dimodifikasi. BSJM kering dihaluskan dengan digiling hingga dihasilkan serbuk. Kemudian disaring dengan saringan diameter kehalusan $1 \mathrm{~mm}$. Bubuk BSJM kemudian diekstraksi dengan metode maserasi menggunakan pelarut etanol $70 \%$, dengan perbadingan 250 gram bubuk jambu monyet untuk 1 liter etanol. Maserasi dilakukan selama 48 jam sambil sesekali digojok setiap 2 jam. Larutan kemudian disaring menggunakan kertas saring dan filtrat yang diperoleh ditampung. Filtrat yang diperoleh dievaporasi menggunakan evaporator dengan suhu $40-50^{\circ} \mathrm{C}$ hingga diperoleh EBSJM pekat.

\section{Pembuatan Bumbu Marinasi dengan EBSJM}

Pada pembuatan bumbu marinasi, EBSJM digunakan sebagai pensubstitusi saus tomat pada berbagai proporsi yang berbeda sehingga dihasilkan 4 formula bumbu. Komposisi bumbu marinasi dapat dilihat secara lengkap pada Tabel 1.

\section{Uji Karakteristik Fisikokimia Bumbu Marinasi}

Uji karakteristik fisikokimia pada bumbu marinasi dengan EBSJM sebagai pensubstitusi saus tomat meliputi viskositas, $\mathrm{pH}$, kadar air, dan total padatan terlarut. Viskositas diukur menggunakan viscometer Ostwald (Pyrex, Jakarta, Rusia) dengan prosedur sebagaimana telah dijelaskan pada petunjuk kerja yang terlampir pada kemasan. 
Pengukuran $\mathrm{pH}$ mengacu pada (Setianto et al., 2016) dengan menggunakan alat $\mathrm{pH}$ meter (Ohaus, ST2100-F. Jakarta, Ameika). Sampel seberat $5 \mathrm{~g}$ ditambah $10 \mathrm{ml}$ aquades dan dihomogenkan kemudian diukur dengan menggunakan $\mathrm{pH}$ meter yang telah dikalibrasi lebih dahulu dengan buffer fosfat $\mathrm{pH} 4$ dan 7 . Pengukuran kadar air diawali dengan cawan petri dikeringkan selama 1 jam dalam oven, kemudian didinginkan selama 15 menit di desikator. Selanjutnya, berat cawan petri ditimbang. Sampel bumbu ditimbang sebanyak 2 gram dan dimasukkan kedalam cawan petri yang telah diketahui beratnya kemudian dikeringkan pada oven pada suhu $100-105^{\circ} \mathrm{C}$ selama 4 jam. Selanjutnya, sampel kering didinginkan di desikator lalu ditimbang. Semua data hasil pengukuran dicatat dan kemudian dikalkulasi dengan mengacu pada (Agustin \& Prananda, 2017). Total padatan terlarut ditentukan dengan mengacu pada (Ihsan \& Wahyudi, 2010) menggunakan hand refraktometer (ATC, 950.032-B, Prancis) yang telah dikalibrasi terlebih dahulu. Sampel sebanyak 5 gram dan $5 \mathrm{ml}$ aquades dicampurkan kemudian diaduk sampai rata. Larutan kemudian diteteskan pada permukaan refraktometer dan diratakan. Skala (batas antara warna oranye dan biru) pada refraktometer dibaca sebagai ${ }^{\circ}$ Brix atau persen sukrosa yang terkandung dalam sampel.

Tabel 1. Bumbu marinasi dengan EBSJM sebagai pensubstitusi saus tomat pada proporsi yang berbeda

\begin{tabular}{lrrrr}
\hline \multicolumn{1}{c}{ Bahan } & \multicolumn{3}{c}{ Perlakuan } & \\
\cline { 2 - 5 } & \multicolumn{1}{c}{$\mathrm{F}_{1}$} & \multicolumn{1}{c}{$\mathrm{F}_{2}$} & \multicolumn{1}{c}{$\mathrm{F}_{3}$} & \multicolumn{1}{c}{$\mathrm{F}_{4}$} \\
\hline EBSJM (ml) & 0 & 5 & 10 & 15 \\
Saus tomat (ml) & 100 & 115 & 110 & 105 \\
Minyak (ml) & 45 & 45 & 45 & 45 \\
Bawang merah (gr) & 200 & 200 & 200 & 200 \\
Bawang putih (gr) & 20 & 20 & 20 & 20 \\
Paprika merah (gr) & 175 & 175 & 175 & 175 \\
Gula palem (gr) & 80 & 80 & 80 & 80 \\
Kecap inggris (ml) & 90 & 90 & 90 & 90 \\
Kaldu sapi blok(gr) & 8 & 8 & 8 & 8 \\
Merica hitam (gr) & 5 & 5 & 5 & 5 \\
Garam (gr) & 5 & 5 & 5 & 5 \\
\hline
\end{tabular}

$\mathrm{F}_{1-4}$ adalah macam formula bumbu marinasi dengan EBSJM sebagai pensubstitusi saus tomat pada proporsi masing-masing sebanyak $0,5,10$, dan $15 \%$.

\section{Uji Kesukaan (Hedonik)}

Bumbu marinasi sebanyak $100 \mathrm{ml}$ di larutkan ke air sebanyak $500 \mathrm{ml}$, kemudian daging ayam yang telah dipotong kecil $3 \times 3 \mathrm{~cm}$ dengan ketebalan $2 \mathrm{~cm}$ di rendam kedalam bumbu marinasi selama 4 jam, selanjutnya dipanggang. Uji kesukaan dilakukan dengan metode skoring test untuk mengetahui tingkat kesukaan terhadap suatu produk. Sebanyak 25 panelis agak terlatih diminta untuk memberikan nilai dari 1- 4 pada empat macam sampel yang diujikan dimana nilai skala menunjukan arti yang berbeda pada masingmasing parameter. Panelis diminta untuk memberikan penilaian terhadap aroma, tekstur, rasa dan kesukaan.

\section{Analisis Data}

Analisis dilakukan menggunakan software SPSS 25.0 for Mac pada taraf kebenaran $95 \% \quad(p \leq 0,05)$. Data hasil uji kualitas viskositas, $\mathrm{pH}$ dan kadar air dianalisis statistik dengan ANOVA (Analysis of Variance). Apabila terdapat pengaruh interaksi maka dilakukan uji lanjutan menggunakan uji Wilayah Berganda Duncan. Data hasil uji total padatan dianalisi secara deskriptif menggunakan persamaan regresi linier. Data hasil uji organoleptik (kesukaan) dianalisis statistic dengan Kruskal Wallis dan dilanjut uji Man-Whitney.

\section{HASIL DAN PEMBAHASAN}

Adanya persamaan karakteristik kimia yaitu kandungan vitamin $\mathrm{C}$ pada buah semu jambu monyet dengan tomat (Oliveira et al., 2020) mendasari kajian optimasi substitusi saos tomat dengan EBSJM dalam pembuatan bumbu steak yang berkualitas. Kualitas tersebut dalam kajian ini ditinjau melalui karakteristik fisikokimia bumbu yang tercipta dan juga dari tingkat kesukaan panelis pada steak yang dihasilkan dari proses marinasi menggunakan bumbu tersebut. Kesukaan panelis dapat menjadi asumsi bahwa marinasi mengandung EBSJM berpotensi sebagai produk bumbu baru untuk pengolahan daging menjadi steak di masa yang akan datang.

\section{Karakteristik Fisikokimia Bumbu Steak}

Karakakteristik fisikokimia bumbu steak yang dikaji meliputi viskositas, $\mathrm{pH}$, dan kadar air sebagaimana dapat dilihat pada Tabel 2. Berdsarakan data Tabel 2 
menunjukan bahwa substitusi EBSJM lebih dari 5\% secara signifikan akan menghasilkan viskositas yang lebih tinggi artinya bumbu makin kental jika dibandingkan dengan tanpa subtitusi EBSJM. Menurut (Lubis, 2018) viskositas menetukan kemudahan suatu molekul bergerak karena adanya gesekan antar lapisan material. Karenanya viskositas menunjukkan tingkat ketahanan suatu cairan untuk mengalir. Nilai viskositas semakin besar berpengaruh juga terhadap nilai kadar air yang semakin turun. Menurut (Apriani et al., 2013) viskositas suatu cairan dipengaruhi oleh kadar air yang ada pada cairan tersebut. Menurut besarnya viskositas dipengaruhi oleh beberapa faktor seperti temperatur, gaya tarik antar molekul dan ukuran serta jumlah molekul terlarut.

Substitusi lebih dari 5\% secara signifikan nilai $\mathrm{pH}$ semakin kecil menunjukan bumbu semakin asam jika dibandingkan dengan tanpa substustusi EBSJM dengan rerata nilainya 4,47-4,74. Nilai $\mathrm{pH}$ dipengaruhi oleh bahan penyusunnya, sebab mulai dari proses pembuatan hingga penyimpanan masing-masing bahan tambahan akan saling mempengaruhi kondisi di dalam bumbu. Nilai $\mathrm{pH}$ yang ada pada suatu produk merupakan hasil kesetimbangan yang ada didalam produk tersebut (Kusnandar, 2019). Rasa alami dari produk pangan sangat dipengaruhi oleh bahan penyusunnya (Iskandar \& Handayani, 2016). Makin tinggi substitusi ekstrak BSJM pada saus tomat dalam bumbu marinasi, $\mathrm{pH}$ makin rendah. Hal ini menunjukan bahwa dengan substitusi ekstrak BSJM pada saus tomat, total asam bumbu bertambah dengan demikian substitusi dapat meningkatkan rasa asam pada bumbu marinasi.

Kadar air semakin menururn pada substitusi lebih dari 5\%. Kadar air yang tinggi dapat menyebabkan produk tersebut lebih mudah rusak. Semakin meningkat presentase total padatan terlarut akan menurunkan nilai kadar air dalam bahan. Hal tersebut didukung oleh (Cahyani et al., 2019) bahwa penururnan kadar air bahan menurun seiring dengan peningkatan komponen lainnya. Air di dalam bahan pangan ada dalam tiga bentuk yaitu air bebas, air terikat lemah atau air teradsorbsi, dan air terikat kuat. Air bebas dan air terikat lemah inilah yang terhitung dalam proses pengukuran kadar air karena jumlahnya yang dominan dibandingkan dengan air terikat kuat yang jumlahnya sangat kecil dan membentuk hidrat dengan beberapa molekul lain dengan ikatan bersifat ionic (Akdogan, 1999). Kadar air menentukan daya awet dari bahan makanan karena mempengaruhi sifat fisik, kimia, perubahan mikrobiologi, dan perubahan enzimatis (Noriko et al., 2012).

Tabel 2. Karakteristik Fisikokimia Bumbu Steak

\begin{tabular}{lcccc}
\hline \hline Parameter & Perlakuan & & & \\
\cline { 2 - 5 } & \multicolumn{1}{c}{$\mathrm{F}_{0}(0 \%)$} & $\mathrm{F}_{1}(5 \%)$ & \multicolumn{1}{c}{$\mathrm{F}_{2}(10 \%)$} & \multicolumn{1}{c}{$\mathrm{F}_{3}(15 \%)$} \\
\hline Viskositas $(\mathrm{cP})$ & $0,47 \pm 0,03^{\mathrm{a}}$ & $0,61 \pm 0,07^{\mathrm{a}}$ & $0,70 \pm 0,16^{\mathrm{b}}$ & $1,11 \pm 0,652^{\mathrm{b}}$ \\
pH & $4,74 \pm 0,90^{\mathrm{a}}$ & $4,63 \pm 0,45^{\mathrm{b}}$ & $4,51 \pm 0,45^{\mathrm{c}}$ & $4,47 \pm 0,05^{\mathrm{c}}$ \\
Kadar Air (\%) & $64,09 \pm 0,57^{\mathrm{a}}$ & $63,15 \pm 0,36^{\mathrm{b}}$ & $62,86 \pm 0,30^{\mathrm{bc}}$ & $62,34 \pm 0,44^{\mathrm{c}}$ \\
\hline
\end{tabular}

Data ditampilkan sebagai mean \pm standar deviasi. Superskrip huruf kecil yang berbeda pada baris yang sama menunjukan adanya perbedaan nyata $(\mathrm{p}<0,05) . \mathrm{F}_{0-3}$ merupakan variasi formulasi bumbu marinasi dengan EBSJM sebagai pensubstitusi saus tomat.

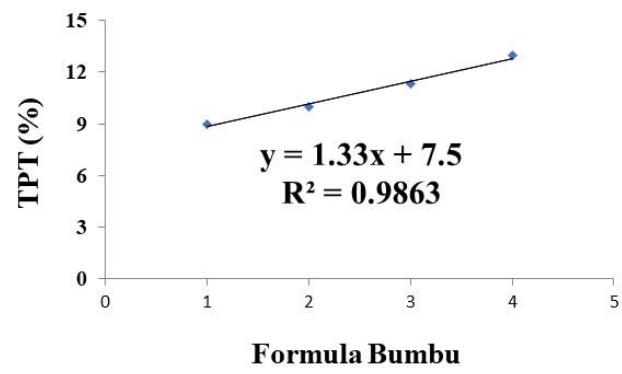

Gambar 1. Total padatan terlarut dari berbagai formula bumbu steak. 1-4 merupakan bumbu dengan substitusi ekstrak BSJM masing-masing sebanyak $0,5,10$, dan $15 \%$.
Selain itu karakteristik fisikokimia juga dicerminkan pada total padatan sebagaimana ditunjukan oleh Gambar 1. Berdasarkan Gambar 1 dapat diketahui bahwa substitusi saus tomat dengan EBSJM pada pembuatan bumbu marinasi mengalami peningkatan pada total padatan produk. Nilai total padatan terlarut semakin meningkat pada substitusi lebih dari 5\%, dikarenakan ektrak BSJM memiliki sejumlah padatan terlarut. Menurut Susanti et al. (2018) terdapat 11,5\% karbohidrat atau 7-9\% kadar gula, 11,7\% padatan larut dan $0,5 \%$ tannin. Kadar air 
mempengaruhi jumlah total padatan dalam bahan pangan karena bahan pangan terdiri total padatan dan air (Akdogan, 1999). Apabila kadar air dalam suatu bahan pangan menurun maka nilai total padatan akan meningkat. Komponen-komponen yang terukur dalam total padatan terlarut meliputi sukrosa, asam organik dan protein.

\section{Evaluasi Hedonik Steak Ayam}

Uji hedonik dilakukan ketika bumbu sudah diaplikasikan ke daging ayam selama 4 jam kemudian dilakukan pemanggangan dan hasilnya diujikan ke 25 panelis semi terlatih. Hasil uji hedonik yang meliputi atribut aroma, rasa, tekstur, dan overall kesukaan dapat dilihat pada tabel 3 .

Berdasarkan Tabel 3 dapat diketahui bahwa hasil analisis sidik ragam menunjukkan substitusi saus tomat dengan EBSJM pada pembuatan bumbu marinasi berpengaruh tidak nyata $(\mathrm{P}>0,05)$ terhadap aroma. Hal ini dikarenakan disubtitusi yang digunakan berupa ektrak dengan maksimal pemberian 5 , 10 dan $15 \%$, sehingga tidak mempengaruhi aroma. Ekstrak artinya hanya mengambil komponen-komponen yang sifatnya bioaktif dan fitokimia sehingga senyawa-senyawa yang bersifat aromatik sudah hilang. Kandungan kimia pada BSJM terdiri dari $79,2 \%$ air, $12 \%$ karbohidrat, $0,16 \%$ protein, $0,2 \%$ lemak, $1,91 \%$ tannin dan $1,13 \%$ asamaskorbat (Maharani et al., 2019). Bahan pangan mengandung karbohidrat dan protein jika dipanaskan akan mengalami pencoklatan non enzimatis, sehingga apabila bahan tersebut dipanaskan akan dapat menghasilkan bau enak. Komponen karbonil yang terbentuk selama proses pemasakan diduga dapat bereaksi dengan asam amino, amin, dan protein menghasilkan flavor yang diinginkan (Lumbong et al., 2017). Umumnya bumbu bersifat aromatik yang tinggi, sehingga bahanbahan penyususn bumbu ikut berpengaruh dalam terbentuknya aroma steak. Manusia dapat mencium bau yang keluar dari makanan dengan adanya sel-sel epitel alfaktori dari bagian dinding atas rongga hidung yang peka terhadap komponen bau (Montolalu et al., 2017).

Rasa merupakan salah satu faktor yang mempengaruhi nilai penerimaan seseorang terhadap suatu makanan. Perlakuan dengan subtitusi $>5 \%$ makin tidak disuka terhadap rasa steak karena terdapat aftertaste pahit yang disebabkan pada proses pemanggangan. Selain itu, proses pemanggangan dan lama pemanggangan mempengaruhi rasa steak yang dihasilkan. (Lumbong et al., 2017) bahwa rasa terbentuk selama pemanggangan dengan adanya proses degradasi atau penguraian senyawa makromolekul daging. Bahan-bahan penyusun bumbu marinasi ikut andil dalam pembentukan rasa steak ayam. Penggunaan bumbu bertujuan untuk meningkatkan citarasa produk (Firahmi et al., 2015).

Tabel 3. Karakteristik Hedonik Steak Ayam yang Diolah dengan Bumbu Marinasi EBSJM

\begin{tabular}{lllll}
\hline \multirow{2}{*}{ Atribut Sensori } & Perlakuan & & \\
\cline { 2 - 5 } & $\mathrm{F}_{0}(0 \%)$ & $\mathrm{F}_{1}(5 \%)$ & $\mathrm{F}_{2}(10 \%)$ & $\mathrm{F}_{3}(15 \%)$ \\
\hline Aroma & $3,28 \pm 0,74$ & $3,08 \pm 0,65$ & $2,88 \pm 0,67$ & $2,8 \pm 0,65$ \\
Rasa & $3,32 \pm 0,72^{\mathrm{a}}$ & $3,24 \pm 0,67^{\mathrm{a}}$ & $2,48 \pm 0,82^{\mathrm{b}}$ & $2,16 \pm 0,8^{\mathrm{b}}$ \\
Teksur & $3,24 \pm 0,72^{\mathrm{a}}$ & $3,44 \pm 0,59^{\mathrm{a}}$ & $2,64 \pm 0,57^{\mathrm{b}}$ & $2,56 \pm 0,59^{\mathrm{b}}$ \\
Kesukaan & $3,24 \pm 0,84^{\mathrm{a}}$ & $3,08 \pm 0,81^{\mathrm{b}}$ & $2,44 \pm 0,82^{\mathrm{b}}$ & $2,22 \pm 0,41^{\mathrm{c}}$ \\
\hline
\end{tabular}

Data ditampilkan sebagai mean \pm standar deviasi. Superskrip huruf kecil yang berbeda pada baris yang sama menunjukan ada perbedaan nyata ( $p>0,05)$. $\mathrm{F}_{0-3}$ merupakan variasi formulasi bumbu marinasi dengan EBSJM sebagai pensubstitusi saus tomat. Skala hedonik 1-4 berturut-turut menyatakan (1) tidak suka, (2) agak suka, (3) suka, dan (4) sangat suka.

Tekstur steak ayam makin tidak disukai dengan subtitusi EBSJM >5\%, hal ini dikarenakan tekstur daging semakin tidak juicy dengan banyaknya EBSJM yang digunakan. Protein yang terkandung di dalam daging ayam bersifat sebaga emulsi, sehingga mampu membentuk tekstur yang baik dan disukai panelis. Sifat mutu daging yang menjadi pertimbangan konsumen salah satunya adalah keempukan daging. Tekstur daging dipengaruhi oleh struktur myofibrilnya dan pada proses marinasi, diduga terjadi reaksi proteolitik yang mampu mengempukan daging dengan cara memecah ikatan peptide menjadi molekul- molekul protein yang lebih sederhana (Zulfahmi et al., 2014). 
Overall kesukaan merupakan parameter yang dicantumkan pada mutu hedonik dari suatu produk. Pada konsentrasi $>5 \%$ rasa steak ayam makin tidak disuka terutama pada atribut rasa dan tekstur. Rerata angka penilaian panelis menunjukan antara agak suka hingga suka dengan overall kesukaan steak ayam. Hal ini dikarenakan uji hedonik overall kesukaan dipengaruhi oleh rasa dan tekstur daging yang dihasilkan (Supit et al., 2013). Overall kesukaan panelis terhadap daging dapat dipengaruhi oleh faktor-faktor yang lain. Menurut (Ismanto \& Basuki, 2017) bahwa aroma, rasa dan tekstur daging mempengaruhi overall kesukaan panelis selain itu preferensi panelis juga mempengaruhi produk yang sedang diuji.

\section{KESIMPULAN}

Optimasi ekstrak BSJM sebagai pensubstitusi saus tomat pada bumbu marinasi steak adalah 5\% ditinjau dari aspek hedonik dengan karakteristik fisikokimia yang lebih kental, asam, dan pekat.

\section{DAFTAR PUSTAKA}

Agustin, H. \& Y. Prananda. 2017. Pengembangan Metode Penetapan Kadar Air Benih Saga Pohon (Adenanthera Pavoninal) Dengan Metode Oven Suhu Rendah Dan Tinggi. Agrin Jurnal Penelitian Pertanian, 21(1): 17-25. https://jurnalagrin.net/ index.php/agrin/article/view/335/250

Akdogan, H. 1999. High moisture food extrusion. International Journal of Food Science \& Technology, 34(3): 195-207.

Apriani, D., Gusnedi, \& Y. Darvina. 2013. Studi tentang nilai viskositas madu hutan dari beberapa daerah di sumatera barat untuk mengetahui kualitas madu. Pillar of Physics, 2(1).

Cahyani, S. O., B. Dwiloka \& H. Rizqiati. 2019. Perubahan Sifat Fisikokimia dan Mutu Hedonik Kefir Air Kelapa Hijau (Cocos nucifera L.) dengan Penambahan High Fructose Syrup (HFS). Jurnal Teknologi Pangan, 3(1): 96-103.
Das, I. \& A. Arora. 2017. Post-harvest processing technology for cashew apple-A review. Journal of Food Engineering, 194: 87-98.

Firahmi, N., S. Dharmawati \& M. Aldrin. 2015. Sifat fisik dan organoleptik bakso yang dibuat dari daging sapi dengan lama pelayuan berbeda. AL ULUM JURNAL SAINS DAN TEKNOLOGI, 1(1).

Ihsan, F. \& A. Wahyudi. 2010. Teknik analisis kadar sukrosa pada buah pepaya. Buletin Teknik Pertanian, 15(1): 10-12.

Iskandar, A. \& M.N. Handayani. 2016. Karakteristik Saus Paprika (Capsicum Annuum) Dengan Penambahan Rosella (Hibiscus Sabdariffa) sebagai Pewarna Alami. EDUFORTECH, 1(1).

Ismanto, A. \& R. Basuki. 2017. Pemanfaatan Ekstrak Buah Nanas dan Ekstrak Buah Pepaya sebagai Bahan Pengempuk Daging Ayam Parent stock Afkir. Jurnal Peternakan Sriwijaya, 6(2).

Ježek, F., J. Kameník, B. Macharáčková, K. Bogdanovičová \& J. Bednář. 2020. Cooking of meat: effect on texture, cooking loss and microbiological quality-a review. Acta Veterinaria Brno, 88(4): 487-496.

Kaprasob, R., O. Kerdchoechuen, N. Laohakunjit, D. Sarkar \& K. Shetty. 2017. Fermentation-based biotransformation of bioactive phenolics and volatile compounds from cashew apple juice by select lactic acid bacteria. Process Biochemistry, 59: 141-149.

Kerth, C. 2016. Determination of volatile aroma compounds in beef using differences in steak thickness and cook surface temperature. Meat Science, 117: 27-35.

Kusnandar, F. 2019. Kimia pangan komponen makro. Bumi Aksara, Jakarta.

Lubis, N.A. 2018. Pengaruh kekentalan cairan terhadap waktu jatuh benda menggunakan falling ball method. Fistek: Jurnal Ilmu Fisika dan Teknologi, 2(2): 26-32. 
Lumbong, R., R.M. Tinangon, M.D. Rotinsulu \& J.A.D. Kalele. 2017. Sifat organoleptik burger ayam dengan metode memasak yang berbeda. ZOOTEC, 37(2): 252-258.

Maharani, A.C., R. Murwani \& S. Susanti. 2019. Pengaruh Pemberian Serbuk Buah Semu Jambu Monyet (Annacardiumaccidentale L.) Sebagai Aditif Pakan Terhadap Profil Serum Lemak Dan Glukosa Broiler. Agromedia, 37(1).

Montolalu, S., N. Lontaan, S. Sakul \& A.D. Mirah. 2017. Sifat fisiko-kimia dan mutu organoleptik bakso broiler dengan menggunakan tepung ubi jalar (Ipomoea batatas L). ZOOTEC, 32(5).

Noriko, N., D. Elfidasari, A.T. Perdana, N. Wulandari \& W. Wijayanti. 2012. Analisis penggunaan dan syarat mutu minyak goreng pada penjaja makanan di food court UAI. Jurnal Al-Azhar Indonesia Seri Sains Dan Teknologi, 1(3): 147-154.

Oliveira, N.N., C.G. Mothé, M.G. Mothé \& L.G. de Oliveira. 2020. Cashew nut and cashew apple: a scientific and technological monitoring worldwide review. Journal of Food Science and Technology, 1-10.

Setianto, Y. C., Y.B. Pramono \& S. Mulyani. 2016. Nilai $\mathrm{pH}$, viskositas, dan tekstur yoghurt drink dengan penambahan ekstrak salak pondoh (Salacca zalacca). Jurnal Aplikasi Teknologi Pangan, 3(3).
Supit, M.A.J., A. Daulima \& B. Badewi. 2013. Penggunaan Beberapa Jenis Sumber Asap Cair Dan Pengaruhnya Terhadap Aroma Serta Cita Rasa Daging Sei (Proses Produksi Alternatif Daging Sei Untuk Keamanan Pangan). Partner, 20(1): 30-42.

Susanti, S., B.E. Setiani, H. Rizqiati, D.R. Febriandi \& V.P. Bintoro. 2018. Inhibitory Activity of Cashew Apple (Anacardium Occidentale) Extract Marinade on the Meat Total Bacteria. Current Research in Nutrition and Food Science Journal, 6(1): 106-112.

Trabelsi, N., S.M. Marotta, F. Giarratana, A. Taamali, M. Zarrouk, G. Ziino \& A. Giuffrida. 2018. Use of Tunisian flavored olive oil as anisakicidal agent in industrial anchovy marinating process. Journal of the Science of Food and Agriculture, 98(9): 3446-3451.

Zulfahmi, M., Y.B. Pramono \& A. Hintono. 2014. Pengaruh marinasi ekstrak kulit nenas (Ananas Comocus L. Merr) pada daging itik tegal betina afkir terhadap kualitas keempukan dan organoleptik. Jurnal Pangan Dan Gizi, 4(2). 